\title{
p53 e as hemopatias malignas
}

\author{
p53 and hematological malignancies
}

Geraldo Barroso Cavalcanti Júnior, 'Claudete Esteves Klumb² e Raquel C Maia ${ }^{3}$

\section{Resumo}

p53 é um gene supressor tumoral, que codifica uma fosfoproteína nuclear que desempenha um papel importante no controle do ciclo celular, no reparo do D N A e na indução da apoptose. Em condições de stress, particularmente por indução de dano no D N A, a proteína p53 bloqueia o ciclo celular, permitindo dessa forma o reparo do D N A ou promovendo a apoptose. Estas funções são efetuadas pela capacidade transcricional da proténa p53 que ativa uma série de genes envolvidos na regulação do ciclo celular. A forma mutada da p53 é incapaz de controlar a proliferação celular, resultando em reparo ineficiente do DNA e na emergência de células geneticamente instáveis. As alterações mais comuns nas neoplasias são mutações pontuais dentro das seqüências codificantes deste gene. $\mathrm{N}$ as hemopatias malignas, estas mutações, freqüentemente do tipo pontuais, têm sido observadas com menor ocorrência do que em tumores sólidos. $\mathrm{N}$ as neoplasias hematológicas estas alterações são mais observadas na crise blástica da leucemia mielóide crônica, progressão da síndrome mielodisplásica para leucemia mielóide aguda, na transformação do linfoma folicular para linfoma de alto grau, na evolução da leucemia linfóide crônica para síndrome de Richter e recorrência de leucemias agudas. Esta revisão tem como objetivo avaliar as alterações do gene p53 nas hemopatias malignas e discutir o significado clínico destas alterações genéticas na patogenia e prognóstico nessas neoplasias.

Palavras-chave: gene p53; hemopatias malignas; mutação.

1Professor assistente do D epartamento de Análises Clínicas e Toxicológicas da Universidade Federal do Rio Grande do $\mathrm{N}$ orte (DACT/UFRN). D outorando do Laboratório de $\mathrm{H}$ ematologia Celular e M olecular do Serviço de $\mathrm{H}$ ematologia do H ospital do Câncer I / IN CA-RJ .

${ }^{2}$ M édica hematologista do Serviço de H ematologia do H ospital do Câncer I / IN CA-RJ. D outoranda do laboratório de H ematologia Celular e M olecular do Serviço de H ematologia do H ospital do Câncer-I / IN CA-RJ.

${ }^{3} \mathrm{M}$ édica hematologista do Serviço de $\mathrm{H}$ ematologia do H ospital do Câncer I / C oordenadora do Laboratório de H ematologia Celular e M olecular do Serviço de H ematologia do H ospital do Câncer-I / IN CA-RJ. Enviar correspondência para R.C.M . E-mail: rcmaia@inca.org.br

Recebido em julho de 2002. 


\begin{abstract}
p53 is a tumor-suppressor gene encoding a nuclear phosphoprotein that plays an important role in the control of normal cell proliferation, repair of D N A damage and apoptosis. U pon cellular stress, particularly the one induced by DNA danage, p53 protein can arrest cell cycle progression, thus allowing the D N A to be repaired; or it can lead to apoptosis. These functions are achieved by the transcriptional properties of $\mathrm{p53}$, which activates a group of genes involved in cell cycle regulation. M utant p53 is no longer able to control cell proliferation, resulting in inefficient D N A repair and emergence the genetically unstable cells. The most common changes of p53 cancers are point mutations within the coding sequences of this gene. In hematological malignancies, mutations of p53 gene or inactivation and stabilization of p53 protein are less common than in solid tumor, and usually consist in missense mutations. In hematological malignancies, these alterations are more observed in the evolution from the chronic phase to blast crisis of chronic mieloid leukemia, from myelodysplastic to acute myeloid leukemia, from follicular to high-grade lymphoma, from chronic lymphoid leukemia to high-grade Richter's syndrome, and from relapsed of acute leukemias. The objective of this review is to characterize the p53 abnormalities in hematological malignancies and discuss the clinical significance of these genetic alterations in the pathogenesis and prognosis.
\end{abstract} Key words p53 genes, hematological malignancies; mutation.

\section{INTRODUÇÃO}

A carcinogênese pode ser compreendida como um processo complexo no qual se encontram envolvidos muitos genes, particularmente os que regulam a estabilidade e o reparo do DNA, crescimento celular, imunidade equimio-resistência às drogas. U m grupo de genes envolvidos nesse processo são aqueles denominados genes supressores tumorais, os quais parecem agir normalmente, como reguladores da proliferação celular. Fazendo parte desse grupo, destaca-se o gene p53 cuja mutação ou inativação está implicada no surgimento do câncer, por levar a um aumento de uma população celular com maior instabilidade genética. ${ }^{1,2}$

Mutações do gene p53 são consideradas as alterações genéticas mais freqüentes nos tumores malignos humanos, ocorrendo em cerca de $60 \%$ das neoplasias. $N$ as hemopatias malignas essas alterações são observadas com menor freqüência que em tumores sólidos estando, porém diretamente relacionadas com aqueles casos que apresentam evolução clínica desfavorável.

\section{ESTRUTURA E FUNÇÃO DO GENE SUPRESSOR TUMORAL p53 E SEU PRODUTO PROTÉICO}

0 gene supressor tumoral p53 encontrase situado no braço curto do cromossomo 17 (região p13.1), tendo como seu produto de transcrição uma proteína nuclear de 53 kilodaltons $(k D)$, denominada proteína 53 (p53). ${ }^{2-8}$ Este gene é altamente conservado, apresentando homologia estrutural entre as espécies tais como o Xenopus laevis, galinha e camundongo. No homem, o gene apresenta peso molecular de $20 \mathrm{~Kb}$, sendo constituído por 11 exons. As regiões situadas entre os exons 5 e 9 são denominadas de sítios quentes de mutação (Figura 1)..$^{2-8}$

A proteína p53 por sua vez, é uma fosfoproteína nuclear constituída por 375 aminoácidos. A forma funcionalmente ativa (selvagem ou wild type), apresenta uma estrutura molecular tetramérica, ou seja, com quatro subunidades básicas idênticas que se juntam, constituindo a forma funcionalmente ativa da molécula. ${ }^{1,4-7} \mathrm{C}$ ada unidade básica da proteína p53 é formada por quatro domínios que representam unidades 
funcionais distintas: a) o primeiro segmento (região amino terminal) é composto por 80 aminoácidos, estando relacionado com a capacidade de transativação de outros genes; b) o segundo domínio (localizado entre os aminoácidos 100 e 300) representa a parte central, sendo responsável pela capacidade de ligação com a molécula de D N A; c) na porção carboxi-terminal, localizam-se os sítios de dimerização e, d) a região de tetramerização das quatro unidades básicas da molécula p53 (Figura 2). ${ }^{5-13}$

A proteína p53 foi descrita pela primeira vez em 1979 como uma fosfoproteína nuclear, formando um complexo com o antígeno $T$ do vírus símio 40 (SV-40), sendo inicialmente referida como proteína oncogênica e em 1989 como gene supressor tumoral. ${ }^{1,4,9,13}$

Q uando uma célula apresenta um al elo do gene p53 normal e outro mutado, a função da proténa p53 fica comprometida, visto que a maioria dos tetrâmeros da molécula apresentará pelo menos uma das subunidades alterada, como por exemplo, a troca de um aminoácido. ${ }^{2} \mathrm{~A}$ forma ativa da proténa p53 tem vida média muito curta (em torno de 6 minutos), devido a sua rápida degradação, 0 que torna extremamente difícil a sua detecção. Ao contrário, as formas mutadas ou inativas tendem a acumular-se no núcleo das células, podendo ser facilmente detectadas por métodos imunológicos como a imunocitoquímica, imuno-histoquimica, Western blot ou citometria de fluxo, ${ }^{3,11-13}$

Figura 1. Representação esquemática do gene p53.

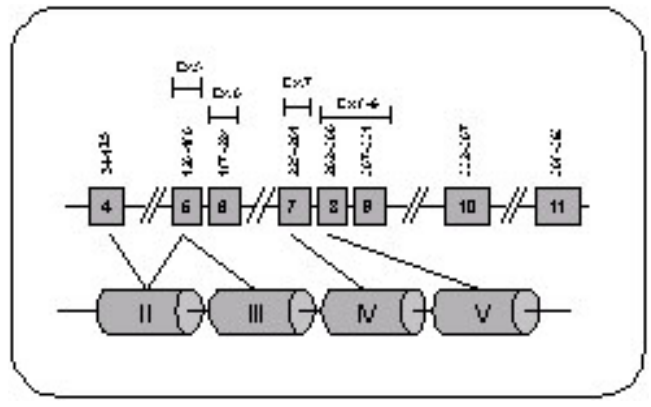

0 gene p53 é constituído por 11 exons. $\mathrm{N}$ as regiões compreendidas entre os exons 5 e 9 situam-se $90 \%$ das mutações observadas nas neoplasias.

Adaptado de: Ichikawa A et al. Blood 1992;79(10):27012707.
Figura 2. Representação esquemática estrutural e funcional da proteína p53.

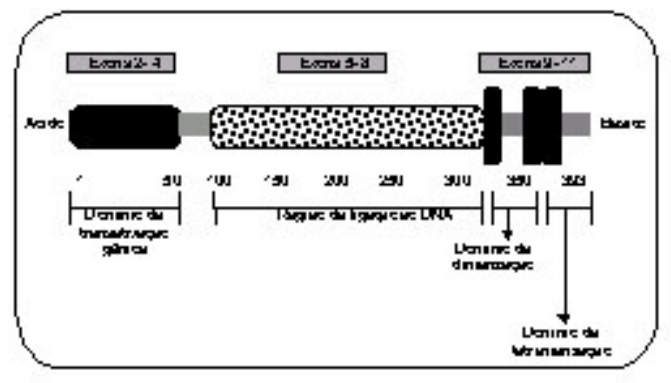

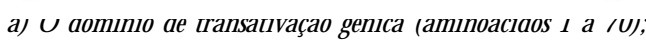
b) a região central, que representa os sítios de ligação da proteína com o DNA (aminoácidos 91 a 301); c) e d) as regiões de dimerização e tetramerização da proteína, respectivamente.

Adaptado de: Prokocimer M. and Rotter V. Blood 1994;84 (8):2391-2411.

0 termo "guardiã do genoma" atribuído à proteína p53 é decorrente da sua função como "policial molecular", monitorando aintegridade do genoma e impedindo a proliferação de células com D N A mutado. ${ }^{14-20} \mathrm{~N}$ o caso de lesão no D N A por agentes físicos tais como radiação ultravioleta, raios gama ou ainda, por produtos químicos mutagênicos, o gene p53 é ativado, levando à transcrição da proteína p53. 0 acúmulo dessa proteína no núcleo da célula inibe o ciclo mitótico no início da fase $\mathrm{G} 1$ e ativa a transcrição de genes de reparo do DN A, impedindo desta forma a propagação do erro genético para as células filhas. $\mathrm{N} o$ entanto, se o reparo do D N A não for efetuado de forma satisfatória, a proteína p53 dispara o mecanismo de morte celular programada denominado apoptose. ${ }^{12,13,16-20} \mathrm{~A}$ capacidade regulatória da transcrição de genes envolvidos na apoptose pode resultar na ativação do gene bax cujo produto de transcrição, a proteína bax, irá inibir a ação antiapoptótica do gene bcl2. 1,4,5,9,10,16-21

No início do ciclo mitótico, o gene p53 ativa transcricionalmente 0 gene $p 21$, induzindo a síntese da proteína 21 (p21), cuja função é inibir a ação das quinases dependentes de ciclina (CD Ks), fazendo com que as células parem na fase $\mathrm{G} 1$ do ciclo celular, até que se complete o reparo do D N A. Para tanto, a proteína p53 ativa o gene Growth Arrest DNA Damage Inducille (GADD -45) que atua corrigindo a lesão no DNA. Quando o reparo do DNA é 
finalizado, a proteína p53 é então degradada pela ação da proteína M D M -2, produto do gene mouse double minute 2 (mdm-2) (Figura 3). ${ }^{16-21} \mathrm{~N}$ as células que apresentam 0 gene $\mathrm{p} 53$ mutado e inativação da proteína p53, não ocorre a parada do ciclo celular necessária para o reparo do DNA. Essas células, geneticamente instáveis, tendem a acumular mutações e rearranjos cromossômicos adicionais, levando a uma rápida proliferação de clones de células com DNA mutado e transformação neoplásica (Figura 4).20-26

A perda da função da proteína p53 pode ocorrer nas seguintes situações: a) por alteração genética; b) interação da proteína p53 com proteínas virais, c) interação da proteína p53 com outras proteínas regulatórias do ciclo celular, como a proteína MDM-2.5,21-24 As alterações genéticas podem ser: mutação pontual (missense), deleção gênica (non sense) de um ou dois alelos do gene p53 e inserção de nucleotídeos na seqüência de D N A. ${ }^{24}$ $M$ utação pontual é a troca de um nucleotídeo e é o tipo de mutação do gene p53 mais freqüentemente encontrado nas neoplasias. Essas mutações ocorrem principalmente entre os codons 120 e 290, situados entre os exons 5 e 9 e resulta com freqüência na transcrição de uma proteína não funcional. A mutação do tipo non sense, por sua vez, pode levar a transcrição de uma proteína truncada e também não funcional. ${ }^{24} D$ entre os métodos de detecção dessas alterações, 0 mais utilizado é a análise do polimorfismo de conformação de fita simples ou single-stranded conformacional polymorphism analysis (SSCP). . $^{3,4,8,15,16}$

U ma mutação no gene p53 seja pontual ou não, altera de forma significativa a proteína p53, o que resulta na incapacidade de efetuar a parada do ciclo celular ou disparar o mecanismo de apoptose. As formas mutadas da proteína apresentam ainda a capacidade de interagir com a proteína selvagem, impedindo a supressão tumoral, sendo este fenômeno conhecido como "efeito dominante negativo", visto que a mutação de um dos alelos do gene p53 produz o que parece ser um efeito dominante sobre 0 alelo normal restante. ${ }^{1-3,29}$

0 antígeno SV-40, a proteína E 1B do adenovírus, a proteína TAX do vírus linfotrópico de células $T$ humano do tipo 1 (HTLV-I) e EBNA5 do vírus Epstein Barr (EBV) quando interagem com a protén na 53 levam a inativação ou estabilização, ao passo que a interação do antígeno E6 do vírus H PV degrada a proteína p53. Esses mecanismos estão provavelmente relacionados à patogênese dessas neoplasias. .,21-24,30 $^{2}$

Figura 3. Ação da proteína p53 na supressão tumoral.

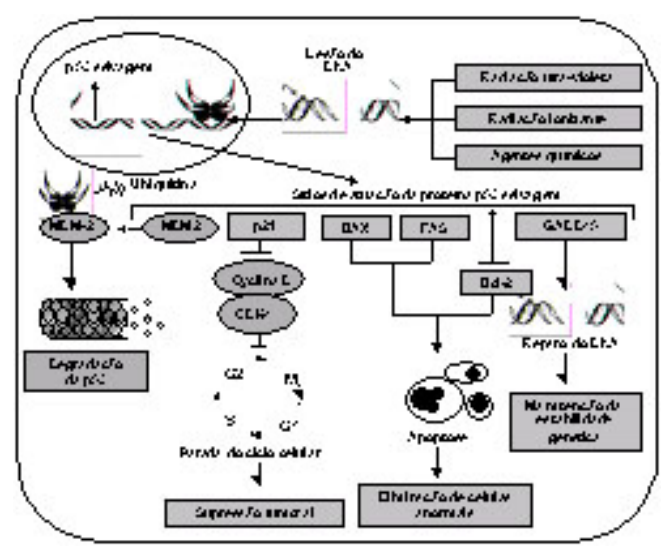

M ediante uma situação de stress que determine lesão no D N A, ocorre a superexpressão da proténa p53 selvagem que atua em alvos espećficos e por mecanismos de transativação gênica ativa outros genes determinando a parada do ciclo celular no início da fase $\mathrm{G} 1$ e o reparo do DNA. Caso a lesão no DNA seja extensa, a p53 ativa genes envolvidos no mecanismo de apoptose, suprimindo a ação de genes com ação anti apoptótica. No final do processo, a proténa p53 é degradada pela ação da proteína M DM -2.

Adaptado de: Bullock AN, and Feisht AR. N ature Rev Cancer $2001 ; 1: 68-75$.

Figura 4. Modelo sugerido para a perda da atividade da proteína p53 culminando com o surgimento de células com instabilidade genética.

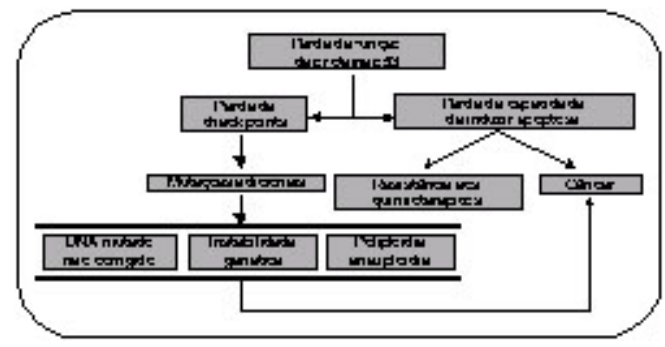

Com a perda da atividade da proteína p53, ocorre a incapacidade das células de efetuar a parada do ciclo celular necessária ao reparo de DNA e a indução da apoptose nas células geneticamente instáveis. 0 corre então a proliferação de clones de células com instabilidade genética e transformação neoplásica.

Adaptado de: El-Deiry WS. Am Soc Clin O ncol (ASCO) / 32N ND annual meeting, may 18-21, 1996;112-118. 


\section{p53 E AS HEMOPATIAS MALIGNAS}

As mutações do gene p53 são consideradas as alterações genéticas mais freqüentes nos tumores malignos humanos, ocorrendo em cerca de $60 \%$ das neoplasias. ${ }^{1,26-28} \mathrm{~N}$ as hemopatias malignas, mutações do gene p53 são observadas com menor freqüência que em outras neoplasias, predominando em doenças com o curso clínico desfavorável (Tabela 1, Figura 5). ${ }^{26-31} \mathrm{~N}$ essas doenças, tem sido observada em muitos casos a associação entre a mutação do gene p53 e a superexpressão da proteína p53 no núcleo das células. ${ }^{34-36}$ Também têm sido detectadas alterações cromossômicas tais como translocações, deleções einversões envolven do principalmente 0 cromossomo 17, além de poliploidias, aneuploidias, e a superexpressão de proteínas de outros oncogenes como cmyc e bcl-2.27-31

$\mathrm{N}$ a rara Síndrome de Li Fraumeni, existe uma predisposição hereditária ao câncer, incluindo vários tipos de neoplasias mal ignas, tais como leucemias agudas, sarcomas em crianças e adultos jovens e câncer de mama em mulheres jovens. Nos indivíduos acometidos por esta síndrome, foi demonstrado que os pais possuíam em suas células germinativas 0 gene p53 mutado. $0 \mathrm{~s}$ pacientes afetados apresentam mutação do gene p53 em um dos alelos demonstrando desta forma a ação desse gene na patogenese desta síndrome. ${ }^{29-31}$

Tabela I. Mutação do gene p53 e características das hemopatias malignas.

\footnotetext{
Evolugio da forma crōnica para críe blástica na leucemia mieloide crōnica.

- Evolugajo da síndrome miebdisplásica para kucemia miebide aguda.

Evolugajo de linfomas de bako grau para alto grau de malignidade.

- Evoluço da kucemia linfóide crōnica para sínd rome de Rizhter.

- Progressáo para fase refratária de miebma múltiplo. - Pecorrēncia da kucemia linfóide aguda de linhagem $\mathrm{E}$ ou $\mathrm{T}$.

- Fecorrēncia da kuogemia miebide aguda.

- aumento do Enōmeno de resistēncia a múltiplas drogas.
}

Adaptado de: Imamura J et al. Blood 1994;84(8):2412 2421.
Em pacientes com leucemia mielóide crônica (LM C), mutações do gene p53 são observadas com freqüência elevada na fase de transformação para a crise blástica, em comparação com a fase crônica, onde apenas $5 \%$ dos casos apresentam o gene p53 mutado. ${ }^{29-31}$ I sto sugere a possibilidade da mutação surgir como evento secundário ao longo da evolução da doença. ${ }^{28-31,35}$ Essas mutações são observadas com maior freqüência em pacientes que desenvolveram crise blástica mielóide quando comparados com indivíduos portadores de LM C em crise blástica linfóide. ${ }^{29-31,35}$

A freqüência de mutação do gene p53 é baixa em pacientes com leucemia linfoblástica aguda (LLA) em comparação com indivíduos portadores de leucemia mielóide aguda (LM A) representando, respectivamente, 3\% e 15\%. Esse percentual aumenta nas recaídas, e em pacientes resistentes ao tratamento. ${ }^{26-32}$

Figura 5. Representação gráfica da freqüência de mutações do gene p53 nas hemopatias malignas.

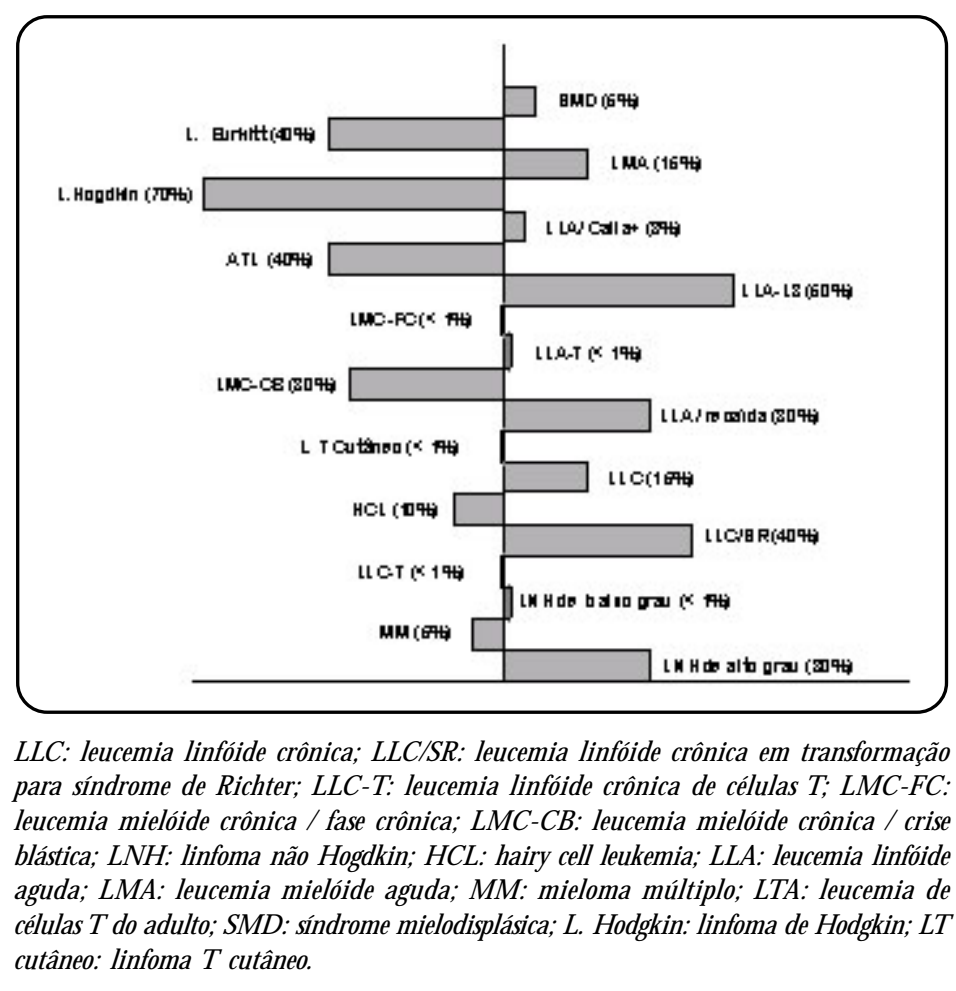

Adaptado de: Imamura J et al. Blood 1994;84(8):2412-2421.

Na LLA do tipo L3 da classificação FAB a freqüência de mutações desse gene é alta, estando presente em cerca de $50 \%$ dos casos. $^{26-32} \mathrm{~N}$ as síndromes mielodisplásicas 
(SM D ), são observadas em cerca de $5 \%$ dos casos, predominando nas formas mais graves como a anemia refratária com excesso de blastos e nos casos que evoluem para LM A, apresentando em muitos casos, monossomia do cromossomo 17 assim como deleção na região $13 p$ do cromossomo $17.29-31,37-38$

$\mathrm{N}$ os pacientes com doenças linfoproliferativas crônicas (DLC), as mutações do gene p53 também têm se correlacionado com as formas clínicas mais graves. D esta forma, nos pacientes com leucemia linfocítica crônica do tipo B (LLC -B) na sua forma clássica, essas mutações têm sido detectadas em cerca de $10 \%$ dos casos, percentual que aumenta na transformação para síndrome de Richter ou leucemia prolinfocítica de células B (LPL-B). N a leucemia linfocítica crônica de células T (LLCT) essas alterações são raras. ${ }^{29-31,39,41}$

Köning et al, ${ }^{42}$ através das técnicas SSC $P$ e seqüenciamento automático de DNA analisaram amostras de 61 pacientes com $\mathrm{H}$ airy cell leukemia (HCL) e observaram mutações do gene p53 em 17 casos (28\%), contrastando este estudo com outros autores que relatam baixa freqüência de mutação do gene p53 na H CL. ${ }^{29-31}$

Em pacientes acometidos com leucemia de células T do adulto (LTA) são observadas mutações do gene p53 em cerca de $40 \%$ das formas agudas, sendo raramente observadas na forma crônica, smoldering e em portadores assintomáticos do H T LV-I. ${ }^{29-31}$ Semelhante ao que ocorre com a LTA, mutações do gene p53 também têm sido observadasnos linfomas relacionados ao EBV. Tanto o H TLV como 0 $E B V$, apresentam capacidade de imortalizar linfócitos in vitro e foi demonstrado que a interação entre 0 antígeno EBN A5 do EBV com a proteína p53 pode levar a sua inativação. ${ }^{24,26,29-31}$

Recentemente, foi demonstrado que células infectadas pelo vírus H TLV-I / II têm alto nível da proteína p53 estabilizada por mecanismo não relacionado à mutação. Estudos da funcionalidade dessa proteína nessas células mostraram ausência de atividade. Como a seqüência da proteína correspondia à forma selvagem, diversos outros estudos investigaram um possível mecanismo de inativação, demonstrando que a expressão da proteína TAX está correlacionada com a inibição da função da proteína p53. ${ }^{31,43-45}$

$\mathrm{N}$ os linfomas não $\mathrm{H}$ odgkin ( $\mathrm{LNH}$ ), mutações do gene p53 foram detectadas em cerca de $30 \%$ dos linfomas de origem B de alto grau. Este achado genético tem sido raramente observado nos linfomas de grau intermediário ou de baixo grau de malignidade. ${ }^{12,29-31} \mathrm{Em}$ pacientes com linfomas associados à infecção pelo H IV (em geral linfomas de alto grau), a freqüência de mutação do gene p53 oscila em torno de 45\% dos casos. 30,31

No linfoma de Hodgkin, por sua vez, a superexpressão da proténa p53 é facilmente detectada pela imuno-histoquímica nas células deR eed-Sternberg, sendo, porém negativa nos eosinófilos e macrófagos presentes no infiltrado tumoral. ${ }^{30,31} \mathrm{~N}$ o entanto, estudos moleculares realizados em material de biópsia, não demonstraram correlação entre a superexpressão da proteína p53 e mutação do gene p53. ${ }^{46,47} \mathrm{Em}$ contraste, outros estudos demonstraram uma freqüência de $75 \%$ ou mais de mutações do gene 553 em preparados celulares com alta concentração de células de Reed-Sternberg, ficando claro o papel relevante da mutação do gene ou inativação da proteína p53 na fisiopatologia do linfoma de H odgkin. . $^{30,31}$

N o mieloma múltiplo (M M ), a ocorrência de mutações do gene p53 é rara, e quando presentes, as mutações se correlacionam com as formas mais graves da doença, geralmente refratárias ao tratamento. ${ }^{30,31}$

Estudos recentes demonstraram a superexpresssão da proteína M D M -2 nas células neoplásicas de pacientes com $L N H$, LLC em estágio avançado, M M , LLA, SM D em franca transformação para LMA e neoplasias não hematológicas. Este achado sugere que a ação da M D M -2 na inativação da proteína p53 pode ser um dos possíveis mecanismos moleculares envolvidos na carcinogênese. ${ }^{48-53}$

Em última análise, a mutação ou inativação do gene p53 pode ocorrer moderadamente nas hemopatias malignas. Este achado genético tem sido particularmente observado na transformação blástica do tipo mielóide da $L M C$, LM A pós SM D, recaídas 
das leucemias agudas, LNH de alto grau e nas formas clínicas mais graves das D LC..$^{29-31}$

\section{PERSPECTIVAS E QUESTÕES PARA O FUTURO}

p53 é o gene mais extensivamente estudado nas neoplasias e pacientes com mutação têm um pior prognóstico. Entretanto, inconsistências na análise dessas alterações impedem a utilização desse conhecimento na prática clínica. A relação entre o tipo de mutação e a evolução clínica deve ser melhor investigada pois possivelmentenem todas as mutações resultam no mesmo efeito. Além disso, algumas mutações podem ser tecido-específicas. ${ }^{54} \mathrm{~A}$ observação que determinadas mutações podem afetar tratamentos específicos poderá auxiliar o clínico na escolha do tratamento. ${ }^{55}$

N os últimos anos numerosas pesquisas em terapia gênica vêm sendo desenvolvidas e representam uma promissora esperança. No campo da farmacologia molecular, progressos na compreensão dos mecanismos bioquímicos de ação da p53 permitirão identificar os alvos moleculares para síntese de novas drogas. Também o desenvolvimento de drogas que possam resgatar a função da proteína mutante, como peptídeos que restaurem a conformação selvagem ou interajam com o domínio de ligação ao D N A, ativando formas mutantes, são estratégias que estão em curso. ${ }^{10,54,55} \mathrm{~A}$ inativação da p53 parece ser um passo essencial em muitas neoplasias, e drogas que possam restaurar esta função terão potencial aplicação.

Está claro que muitas questões sobre a função da p53, as proteínas e sinais envolvidos nesta via ainda não estão respondidas, mas a continuidade das pesquisas poderá levar ao sucesso de algumas dessas estratégias resultando em benefício para milhares de pacientes.

\section{AGRADECIMENTOS}

Os autores agradecem ao Dr. M arcos Scheiner por sua ajuda no preparo das figuras.

\section{REFERÊNCIAS BIBLIOGRÁFICAS}

1. Yonish-Rouach E. A question of lifeor death: the p53 tumor supressor gene. Pathol Biol 1997;45(10):815-23.

2. $\mathrm{H}$ arris $\mathrm{CH}, \mathrm{H}$ ollstein $\mathrm{M}$. C linical implications of the p53 tumor supressor gene. $\mathrm{N}$ Engl J Med 1993;239:1318-26.

3. M ilner J. Structures and functions of the tumour suppressor p53. Pathol Biol 1997;45(10):797-803.

4. M owat M RA. P53 in tumour progression: life, death and everything. Adv Cancer Res 1998;74:25-48.

5. M artin A. Legéne suppresseur detumeur p53 ( $1^{\text {re }}$ partie): structure, function et mécanismes d'inativation. Ann Pathol 1995;15(3):178-83.

6. Beroud C, Soussi T. p53 genemutation: software and database. N ucleic Acids Res 1998;26(1):200-4.

7. Wolkowiz R, RotterV. TheD N A binding regulatory domain of $\mathrm{p53}$ : see the $\mathrm{C}$. Pathol Biol 1997;45(10):785-96.

8. Jayraman $L$, PrivesC. Covalent and noncovalent modifiers of the p53 protein. Cell M ol LifeSci 1999;55:76-87.

9. Janus F, Albrechtsen N, Dornreiter I, W iesmüller L, GrosseF, D epper W. Thedual rolemodel for p53 maitaining genomic integrity. Cell M ol LifeSci 1999;55:12-27.

10. Bullock AN , FeishtAR. Rescuingthefunction of mutant P53. N atureRev Cancer 2001;1:68-75.

11. VandeWandeG F, Klein G. p53 in tumor progression: life, death and everything. Adv Cancer Res 1998;74:25-48.

12. Prokocimer $M$, Rotter $V$. Structureand function of p53 in normal cells and their aberrations in cancer cells: projection on thehematologic cell lineages. Blood 1994;84(8):2391-411.

13. M ay $P, M$ ay E. p53 et cancer. Pathol Biol 1995;43(3):165-73.

14. Lane D P. p53, guardian of the genome. $\mathrm{Na}$ ture 1992;358:15-6.

15. Koshland DE. The molecule of the year. Science 1993;262:1954.

16. M organ SE, Kastan M B. p53 and AT M : cell cycle, cell death and cancer. Adv Cancer Res 1997;71:2-25.

17. Tarapore P, Fukasawa K. P53 mutation and mitotic infidelity. Cancer Invest 2000;18(2):148-55.

18. H upp T R, LaneD P, Ball K. Strategies for ma- 
nipulating the p53 pathway in the treatment of human cancer. Biohem J 2000;352:1-17.

19. Kastan M B, O nyekwere O, Sidransky D, et al. Participation of p53 protein in the cellular response to DNA damage. Cancer Res 1991;51:6304-11.

20. Almong A, Rotter V. An insight into lifeof $p 53$ : a protein coping with many functions! Bioquem Biophys Acta 1998;1378:43-54.

21. EI-D eiry WS. The 533 tumor gene supressor gene: benche to bedside. Proc Am Soc Clin Oncol 1996:112-8.

22. SteeleRJC, Thompson AM , H all PA, LaneD P. The p53 tumour suppressor gene. $\mathrm{Br}$ J Surg 1998;85:1460-7.

23. Sidransky D, H ollstein M. C linical implications of the p53 gene. Annu Rev Med 1996;47:285-301.

24. Soussi T. Cycle cellulaire et apoptose: le gene suppreseur de tumeur p53. M ed Sci 2000;16:496-472.

25. Prives $\mathrm{C}, \mathrm{H}$ all P. The p53 pathway. J Pathol 1999;187:112-26.

26. Ratter V, Prokocimer M . p53 and human malignancies. C ancer Res 1991;57:257-72.

27. Soussi T, D ehoucheK, Béroud C. L'anallisedes mutationsdu gènep53 danslescancershumains: lelien entrel'épidémiologieet la carcinogenèse. M ed Sci Synth 2000;16:1378-96.

28. M artin A. Legénesuppresseur detumeur p53 (2a partie): applicationsen pathologiehumaine. Ann Pathol 1995;15(3):184-91.

29. Fenaux P. The clinical significance of thep53 supressor genein haematological malignancies. $\mathrm{BrJ} \mathrm{H}$ aematol 1997;98:502-11.

30. PreudhommeC, Fenaux P. p53 et hemopathies malignes. Pathol Biol 1997;45(10):777-908.

31. ImamuraJ, M iyoshi I, Koeffler P. p53 in hematologic malignancies. Blood 1994;84(8):2412-21.

32. D iacciannni M B, YU J, H siao M , M ukherjee $L$, Shao E, Yu AL. Clinical significance of p53 mutationsin relapsed T-cell acutelymphoblastic leukemia. Blood 1994;(9):3105-12.

33. Rotter V, Prokocimer M . p53 and human malignancies. Adv Cancer Res 1991;53:257-72.

34. PaydasS. p53 protein expression in leukemias. Acta O ncol 1995;34(1):23-6.

35. KonikovaE, Kuseuda O , Babusikova I. Flow cytometry of p53 protein expression in some hematological malignancies. $\mathrm{N}$ eoplasma 1999;46(6):368-76.

36. Konikova E, Kusenda J . p53 protein expres- sion in leukemia and lymphoma cells. N eoplasma 2001;48(4):290-8.

37. Kitagawa M , YoshidaS, KumataT, TanizawaT, Kamiyama R. p53 expression in myeloid cells of myelodysplastic syndromes. Association with evolution of overt leukemia. Am J Pathol 1994;145(2):338-44.

38. Lai JL, PreudhommeC, Zamdecki M , Flactif $M$, Vanrumbeke $M$, Lepelley $P$, et al. $M$ yelodysplastic syndromesand acutemyeloid leukemia with $17 q$ del etion. An entity characterized by specific dysgranulopoiesis and high incidence of p53 mutations. Leukemia 1995:370-81.

39. Gaidano G, Ballerini P, Gong JZ, et al. p53 mutation in lymphoid malignancies: association with Burkitt lymphoma and chronic lymphocytic leukemia. Proc N atl Acad Sci U SA 1991;88:5413-7.

40. Ichikawa A, H ota T, Takagi N, Tsushita K, Kinosshita T, $\mathrm{N}$ agai $\mathrm{H}$, et al. M utation of p53 geneand their relation to diseaseprogression in Bcell lymphoma. Blood 1992;79(10):2701-7.

41. CordoneL, M asi S, M auro FR, Soddu S, M orsilli 0 , Valentini T, et al. p53 expression in B-chronic lymphocytic leukemia: a marker of diseaseprogression and poor prognosis. Blood 1998;91(11):4342-9.

42. Köning EA, Kusser WC, D ay $C$, Porzsolt $F$, G lickman BW, M esser G, et al. p53 mutation in hairy cell leukemia. Leukemia 2000;14:706-11.

43. Pise-M asison $C A, M$ ahieux $R$, Radonovich $M$, Jiang H, D uvall J, Guillerm C, et al. Insights into the molecular mechanism of p53 inhibition by H TLV type 1 tax. AID S Res H uman Retroviruses 2000;16(16):1669-75.

44. M ahieux R, Pise-M asison CA, N icot C, G reen P, Brady JN . Inactivation of p53 by H TLV type 1 and H T LV type 2 tax trans-Activators. AIDS Res Human Retroviruses 2000;16(16):1677-81.

45. Takemoto $S$, Trovato $R, C$ ereseto $C, N$ icot $C$, KislyakovaT, C asareto L, et al. P53 stabilization and functional impairment in theabsence of genetic mutation or the alteration of the p14ARF-M D M -2 loop in ex vivo and cultured adultT-cell leukemia/ lymphoma cells. Blood 2000;95(12):3939-40.

46. Chan WC. The Reed-Sternberg cell in clinical H odgkin'sdisease H ematol O ncol 2001;19:1-17.

47. Elenitoba-J ohnson KSJ, M edeirosLJ, Khorsand J, King T C. p53 expression in Reed-Sternberg cells does not correlatewith gene mutations in Hodgkin's disease. Am J Clin Pathol 1996;106(6):728-38. 
48. H orie S, Endo K, Kawasaki H, Terada T. $O$ verexpression of M D M -2 protein in intrahe patic cholangiocarcinoma: relationship with p53 overexpression, ki-67 labeling, and clinicopathological features. Virchows Arch 2000;437:25-30.

49. Tzardi M, Kovidou CR, Panaviotides I, Stefanaki K, Rontogianni D, ZoisE, Koutsoubi $\mathrm{K}$, et al. p53 protein expression in non$H$ odgkin'slymphoma: comparativestudy with thewild typep53 induced protein $\mathrm{mdm}-2$ and p21/walf-1. J Clin Pathol 1996;49:278-82.

50. Zhou M , Gu L, AbshireTC, H omansA, Billett $A L$, Yeager AM , et al. Incidenceand prognostic significance of MDM-2 oncoprotein overexpression in relapsed childhood acutelymphoblastic leukemia. Leukemia 2000;14:61-7.

51. Lozano G, O ca Luna RM . 1M D M -2 function. Biochem Biophys 1988;1377:55-9.
52. Bálinit E, Vousden KS. Activation and activities of the 53 tumour suppressor protein. $\mathrm{Br}$ J Cancer 2001;85(12):1813-23.

53. Bueso-Ramos CE, $M$ anshouri $T$, $H$ aidar $M A$, Yo H , Keating M J, Albitar M . M ultiplepatterns of M D M -2 desregulation in human leukemias: implications in leukemogenesis and prognosis. Leuk Lymphoma 1995;17(1-2):13-8.

54. Ribeiro RC, Sandrini F, Figueiredo B, Zambetti $G P, M$ ichalkiewicz $E$, Lafferty $A R$, et al. An inheyed p53 mutation that contributes in a tissue-specific manner to pediatric adrenal cortical carcinoma. Proc N atl Acad Sci U SA 2001;98(16):9330-5.

55. Soussi T, Béroud C. Assessing T P53 status in human tumoursto evaluateclinical outcome. $\mathrm{N}$ ature Rev C ancer 2001;1:233-9.

56. Vogeslstein B, Kinzler KW. Achilesheel of cancer? $\mathrm{N}$ ature 2001;412:865-6. 